\title{
Effect of a new condensation product on electrodeposition of zinc from a non-cyanide bath
}

\author{
GANESHA ACHARY, H P SACHIN, Y ARTHOBA NAIK* and T V VENKATESHA \\ Department of PG Studies and Research in Chemistry, School of Chemical Sciences, Kuvempu University, \\ Shankaraghatta 577 451, India
}

MS received 9 February 2007; revised 30 April 2004

\begin{abstract}
Zinc electrodeposition from sulphate chloride bath was carried out in presence of condensation product formed between chitosan and veratraldehyde. The bath constituents and operating parameters such as pH, temperature and current density were optimized through Hull cell experiments. Current efficiency and throwing power were measured. Polarization study revealed high shift of potential towards negative direction in the presence of addition agents. Corrosion resistance test revealed good protection of base metal by zinc coating obtained from developed electrolyte. SEM photomicrographs showed fine-grained deposit in the presence of condensation product. The IR spectrum of the deposit showed inclusion of the condensation product during electroplating. The consumption of brightener in the lab scale was $5 \mathrm{mLL}^{-1}$ for 1000 amp-h.
\end{abstract}

Keywords. Chitosan; condensation product; electroplating of zinc; Hull cell studies.

\section{Introduction}

Electroplated zinc coatings are considered to be one of the main ways for the corrosion protection of steel. Cadmium has been extensively used as a barrier coating for steel in aerospace, electrical, and fastener industries owing to its excellent corrosion resistance and other engineering properties (Baldwin and Smith 1996). However, due to their high toxicity and hydrogen embrittlement properties, alternate coatings to cadmium are being actively explored (Ashur et al 1996; Safranck 1997; Basker Veeraraghavan et al 2003). The most commonly used sacrificial coating is zinc and its alloys. Zinc by virtue of its low standard electrode potential $\left(E_{0}=-0.76 \mathrm{~V}\right.$ vs NHE), acts as a sacrificial coating on steel (Swathirajan 1986). To give a thin electrocoating of zinc on steel, various baths are employed. Among these, sulphate baths are gaining importance because of their non-polluting nature (Arthoba Naik et al 2002). Organic additives are often used in electroplating operations in order to obtain smooth deposits, improved throwing power and satisfactory silvery gray appearance (Senthil Kumar et al 2001). To achieve this, combination of two or three, sometimes even more addition agents are used. Presence of many addition agents in the bath poses problem in determining the consumption of brightener during electroplating and some addition agents also cause pollution and health hazard (Arthoba Naik and Venkatesha 2005).

In the present work, efforts have been made to develop a bath solution containing a single addition agent, which is

*Author for correspondence (drarthoba@yahoo.co.in) easily soluble in water and increases the deposition potential. Many researchers (Kariyanna et al 2003; Kariyanna and Venkatesha 2005) have revealed that condensation products of aldehydes and amines are good brighteners than single aldehyde or amine in the bath solution. This may be due to the presence of $>\mathrm{C}=\mathrm{N}$-group in the molecule. Various amines and aldehydes were subjected to condensation reaction (Chen and Martell 1987; Hoss and Elias 1993; Ashassi-Sorkhabi et al 2005) and studied in a basic zinc sulphate bath. Among these, the condensation product formed between chitosan and veratraldehyde is effective in getting quality deposit.

\section{Experimental}

The chemicals used were of AR grade and easily soluble in water. For the preparation of solutions, distilled water was used. The standard $267 \mathrm{~mL}$ Hull cell was used to optimize the bath constituents. The Hull cell experiments with bath solutions (table 1) were carried out without agitation. The $\mathrm{pH}$ of the solution was adjusted with $10 \%$ sulphuric acid or sodium carbonate solution. Zinc metal of $99.99 \%$ purity was used as anode. The anode was activated each time by immersing in $10 \% \mathrm{HCl}$ followed by water wash. Mild steel plates (AISI-1079) of standard Hull cell size were mechanically polished to obtain smooth surface and degreased by dipping in boiling trichloroethylene. The scales and dust on steel plates were removed by dipping in $10 \%$ $\mathrm{HCl}$ solution and were subjected to electrocleaning process. Then these steel plates were washed with water and used for experiments as such. After the plating experiment, the 


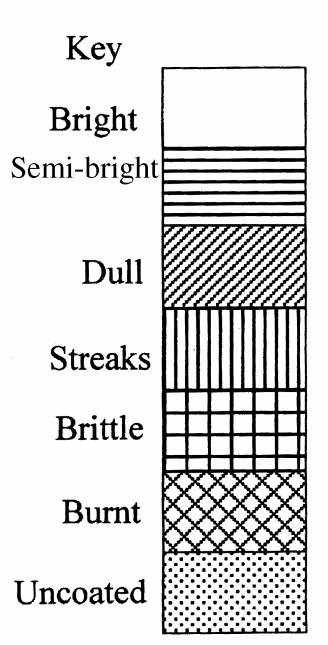

(a)

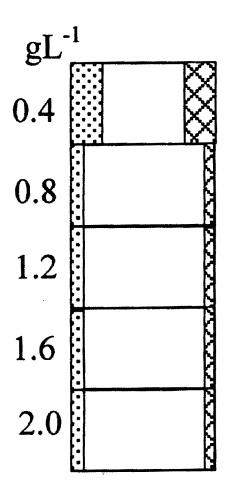

(e)

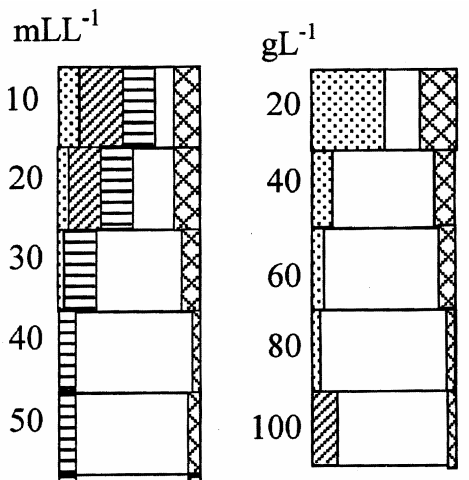

(c)

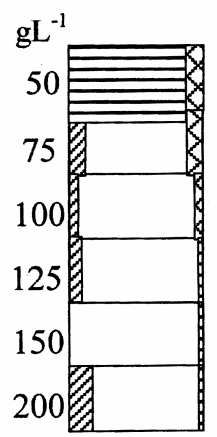

(d)
70

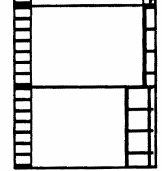

(b)

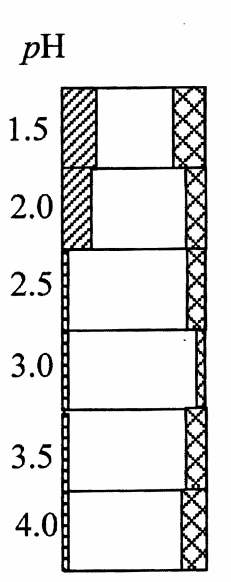

Temp(K)

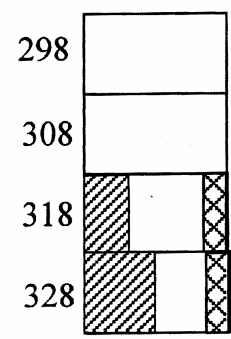

(g)
Current(A)

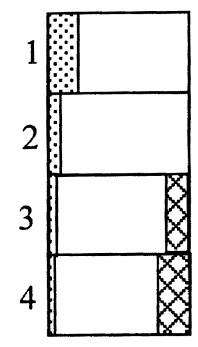

(h)

(f)

Figure 1. Hull cell figures for the zinc electroplating: (a) key, (b) effect of condensation product, (c) effect of $\mathrm{ZnSO}_{4}$, (d) effect of $\mathrm{NH}_{4} \mathrm{Cl}$, (e) effect of SLS, (f) effect of $\mathrm{pH},(\mathrm{g})$ effect of temperature, and (h) effect of cell current.

Table 1. Basic bath composition and operating conditions.

\begin{tabular}{lcl}
\hline $\begin{array}{l}\text { Bath } \\
\text { composition }\end{array}$ & Quantity $\left(\mathrm{gL}^{-1}\right)$ & \multicolumn{1}{c}{ Operating conditions } \\
\hline $\mathrm{ZnSO}_{4} \cdot 7 \mathrm{H}_{2} \mathrm{O}$ & 100 & Anode: zinc metal (99.99\%) \\
$\mathrm{NH}_{4} \mathrm{Cl}$ & 200 & Cathode: mild steel \\
Wetting agent & 04 & Temperature: $298-303 \mathrm{~K}$ \\
\hline
\end{tabular}

plates were subjected to bright dip in $1 \%$ nitric acid for a few seconds followed by water wash. The nature and appearance of zinc plating was carefully studied and recorded through the Hull cell codes (figure 1a).

The condensation product formed between chitosan with chemical formula, $\left(\mathrm{C}_{6} \mathrm{H}_{11} \mathrm{O}_{4} \mathrm{~N}\right)_{n}$ (AR grade, Sisco-chem industries, Mumbai, India) and veratraldehyde with chemical formula, $\mathrm{C}_{9} \mathrm{H}_{10} \mathrm{O}_{3}$ (AR grade, s.d. fine chemicals, Mumbai, India) was added to the bath solution. Condensation product was synthesized by dissolving $2.5 \mathrm{~g}$ of chitosan in $50 \mathrm{~mL}$ of $3 \mathrm{~N}$ acetic acid and the resultant solution was stirred for $2 \mathrm{~h}$. To this solution $1 \mathrm{~g}$ of veratraldehyde was added with stirring. The resultant mixture was heated to about $333 \mathrm{~K}$ for $30 \mathrm{~min}$ on a water bath. The completion of the reaction was tested by TLC (Brian et al 1997).

All the experiments were conducted at $303 \pm 1 \mathrm{~K}$. Known amount of condensation product was added to the plating bath, the bath solution was stirred for $30 \mathrm{~min}$ and then used for Hull cell experiments.

The deposits were obtained at a constant current density from the optimized solution taken in a rectangular methacrylate cell of 2.51 capacity. Polished, degreased and electro cleaned cathodes of $3 \times 4 \mathrm{~cm}^{2}$ were used for plating. Experiments were done in triplicate. Standard experimental procedures (Parthasaradhy 1989) were adopted for the measurement of metallurgical properties of the deposit such as ductility, hardness, adherence etc. In all the above studies, the average thickness of the deposit was $20 \mu \mathrm{m}$. 
For corrosion resistance test, the coated steel plates of $3 \times 4 \mathrm{~cm}^{2}$ area were given bright dip followed by passivation in a solution containing $200 \mathrm{gL}^{-1}$ of sodium chromate and $2 \mathrm{mLL}^{-1}$ of sulphuric acid at $303 \mathrm{~K}$ for $5 \mathrm{~s}$. These passivated samples were dried for $24 \mathrm{~h}$ in a clean atmosphere and subjected to neutral salt spray test in accordance with ASTM standard method B-117 using 5\% neutral sodium chloride solution at $303 \mathrm{~K}$.

Polarization studies were carried out by using a threecompartment cell. The area of zinc anode was $2 \mathrm{~cm}^{2}$. Mild steel was used as cathode with an exposed area of $2 \mathrm{~cm}^{2}$. The cathode potential was recorded galvanostatically with respect to saturated calomel electrode, at different current densities. Haring and Blum cell was used to measure throwing power of the bath solution and a rectangular methacrylate cell was used to measure current efficiency. For throwing power measurement the current distribution ratio between anode and cathode was $1: 5$. For determining consumption of brightener, a rectangular cell of $2.51 \mathrm{ca}-$ pacity was used. SEM photomicrographs were taken to know the nature of deposit in the presence of addition agents.

The more useful method for measuring micro hardness involves making an indentation with indenter of specified geometry under specified load. The length of indentation is measured and micro hardness is calculated (Vickers hardness tester, British make). The value is expressed in Vickers hardness number (VHN).

To know the amount of addition agents consumed in the bath, 2.51 of bath solution was taken and plating was carried out at different current densities. The total number of coulombs passed to the bath solution was recorded at the time when the bath just started to give semi-bright deposit. The bath solution after use was subjected to Hull cell test by adding different amounts of condensation product. The concentration of the condensation product, at which once again bright deposit was obtained, was determined.

\section{Results and discussion}

\subsection{Hull cell studies}

3.1a Effect of condensation product: Basic bath solution gave coarse dull deposit between the current density range of 1 and $7 \mathrm{Adm}^{-2}$ at $2 \mathrm{~A}$ cell current. The synthesized dark yellow condensation product was diluted to $50 \mathrm{~mL}$ with distilled water and a known amount of this solution was added to the electroplating bath solution.

At lower concentrations of the product, the deposit was semi-bright between the current density range of 1 and $7 \mathrm{Adm}^{-2}$. At lower current density, dull and at higher current density, burnt deposits were obtained. With increase in concentration, the nature of deposit was improved and at a concentration of $40 \mathrm{mLL}^{-1}$ of the condensation product, the Hull cell panels were bright between the current density range of 0.5 and $8.0 \mathrm{Adm}^{-2}$. With further increase in the concentration of the condensation product the nature of the deposit became brittle at higher current density region. Therefore, on the basis of the above observations the concentration of the condensation product was kept at $40 \mathrm{mLL}^{-1}$ as optimum. The appearance of Hull cell panels showing the effect of condensation product is given in figure $1 \mathrm{~b}$.

3.1b Effect of zinc sulphate: To find out the effect of zinc metal ion concentration, zinc sulphate concentration was varied from $20-100 \mathrm{gL}^{-1}$. At lower concentrations, the bright deposit was observed in the current density range between 2 and $6 \mathrm{Adm}^{-2}$ (figure 1c). At lower current density region, uncoated and at higher current density region, burnt deposits were obtained. With increase in the concentration of zinc sulphate, the brightness range was extended to higher and lower current density regions. At a concentration of $80 \mathrm{gL}^{-1}$, satisfactory bright deposit was obtained in the current density range $1-8 \mathrm{Adm}^{-2}$ at $2 \mathrm{~A}$ cell current. With further increase in the concentration of zinc sulphate no improvement in the nature of deposit was observed. The concentration of zinc sulphate was fixed at $80 \mathrm{gL}^{-1}$ as optimum.

3.1c Effect of ammonium chloride: To increase the conductivity of the bath solution certain conducting salts having chlorides and sulphate are added. Some of these salts not only act as conducting salts but also influence the nature of deposition and dissolution of the anode. Ammonium chloride produced bright deposits in the wide current density range. The concentration of ammonium chloride was varied from $50-200 \mathrm{gL}^{-1}$ in the bath solution. At lower concentrations $\left(<150 \mathrm{gL}^{-1}\right)$, the Hull cell cathode suffers dull and semi-bright deposit in the low and high current density regions. At a concentration of $150 \mathrm{gL}^{-1}$, the deposit was mirror bright in the entire current density range at $1 \mathrm{~A}$ cell current (figure 1d). Higher concentration $\left(>150 \mathrm{gL}^{-1}\right)$ gave a dull deposit, which was observed in the high current density region. The amount of ammonium chloride was fixed at $150 \mathrm{gL}^{-1}$ in the bath solution.

3.1d Effect of wetting agent: In the Hull cell studies sodium lauryl sulphate (SLS) was used as wetting agent and the concentration of SLS was varied from $0 \cdot 4-2 \mathrm{gL}^{-1}$. The bright deposit was obtained at a concentration of $2 \mathrm{gL}^{-1}$ (figure $1 \mathrm{e}$ ).

3.1e Effect of $\mathrm{pH}$ : To study the effect of $\mathrm{pH}$, the bath $\mathrm{pH}$ was varied from 1-4 (figure 1f). At higher $\mathrm{pH}(>3)$, the Hull cell panels showed burnt deposit at high current density range. At $\mathrm{pH} 3$ satisfactory bright deposits were obtained. At still lower $\mathrm{pH}(<3)$, the specimen contained uncoated area at low current density region and burnt at high current density region. From the above observation, $\mathrm{pH}$ of the bath solution was kept at 3 as optimum. 
3.1f Effect of temperature: To know the effect of temperature on Hull cell experiments, the plating experiments were carried out in a thermostat. The temperature of the thermostat was varied from 298-328 K. At lower temperature $(<308 \mathrm{~K})$, the deposition was bright in the current density range between 1 and $8 \mathrm{Adm}^{-2}$ at $2 \mathrm{~A}$ cell current (figure $1 \mathrm{~g}$ ). Above $308 \mathrm{~K}$ the deposition was dull in low current density range. So the optimum temperature range was $298-308 \mathrm{~K}$.

$3.1 \mathrm{~g}$ Effect of cell current: The Hull cell experiments were carried out at different cell currents (1-3A) for $5 \mathrm{~min}$ using optimum bath solution. It was found that at a cell current of $1 \mathrm{~A}$ the deposit was bright in the current density range $0-4 \mathrm{Adm}^{-2}$. At a cell current of $2 \mathrm{~A}$, the deposit was bright in the current density range $0.5-8 \mathrm{Adm}^{-2}$ (figure $1 \mathrm{~h})$. At a cell current of $3 \mathrm{~A}$, the Hull cell panels showed burnt deposit at higher current density region. This observation revealed that the bath gave bright deposit in the current density range $0 \cdot 5-8 \mathrm{Adm}^{-2}$.

\subsection{Current efficiency and throwing power}

Current efficiency and throwing power were measured at different current densities by using optimized bath solution

Table 2. Current efficiency and throwing power for optimum bath solution at different current densities.

\begin{tabular}{lcc}
\hline $\begin{array}{l}\text { Current density } \\
\left(\mathrm{Adm}^{-2}\right)\end{array}$ & $\begin{array}{c}\text { Current efficiency } \\
(\%)\end{array}$ & $\begin{array}{c}\text { Throwing power } \\
(\%)\end{array}$ \\
\hline 1 & 91 & 26 \\
2 & 93 & 29 \\
3 & 94 & 30 \\
4 & 91 & 23 \\
5 & 88 & 21 \\
\hline
\end{tabular}

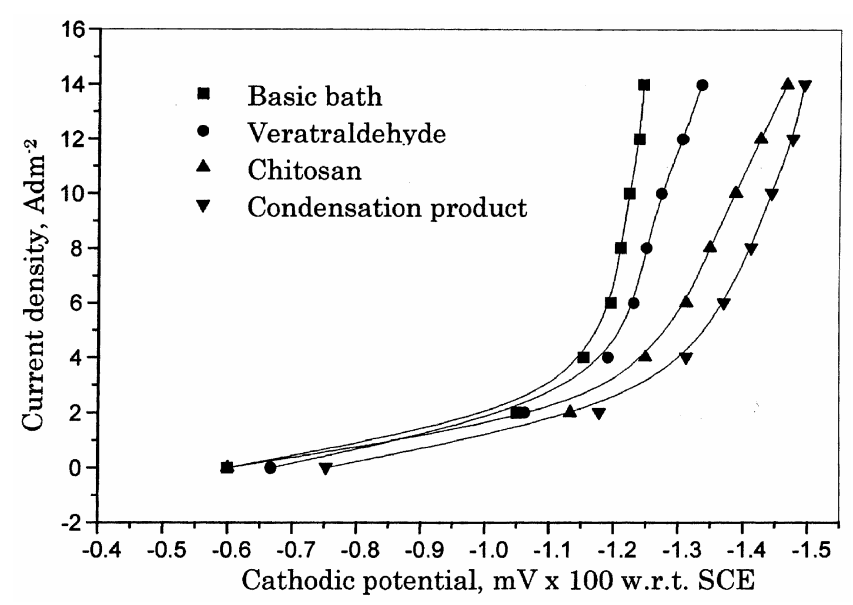

Figure 2. Effect of addition agents on cathodic potential. (table 2). At $1 \mathrm{Adm}^{-2}$, the current efficiency was found to be $91 \%$ (table 3 ). At a current density of $2 \mathrm{Adm}^{-2}$, the current efficiency was found to be $93 \%$. With increase in the current density above $3 \mathrm{Adm}^{-2}$, the current efficiency was found to be decreased and at $5 \mathrm{Adm}^{-2}$ it was $88 \%$. The throwing power is noticed in the range $21-30 \%$.

\subsection{Polarization studies}

The potential of steel cathode was measured galvanostatically with respect to saturated calomel electrode at different current densities. The variation of potential in the presence of different bath constituents is shown in figure 2 . The shift in cathodic potential towards negative direction was observed in presence of addition agents.

\subsection{Surface morphology and IR studies}

The nature of crystal growth in the presence and absence of addition agents is explained with the help of SEM photomicrographs (figure 3 ). In figure $3 a$, the crystal growth is not uniform, the basic bath produced a deposit having different and slightly larger crystal sizes but in the presence of veratraldehyde there is a formation of deposit with refined crystal growth (figure $3 b$ ). SEM photomicrographs of the deposit obtained from the optimized bath showed a uniform arrangement of the crystals, refinement in the crystal size and hence gave a bright deposit (figure 3c). SEM image of the passivated deposit obtained from the optimized bath is shown in figure $3 \mathrm{~d}$.

The IR spectrum of the scrapped deposit obtained from the optimized bath (figure 4) was used to determine inclusion of an organic compound in the deposit. The IR spectrum contains peak at $1670 \mathrm{~cm}^{-1}$ which corresponds to $>\mathrm{C}=\mathrm{N}$ stretching. The absorption peaks in the IR spectrum revealed the inclusion of addition agent in the deposit during electrodeposition.

\subsection{Corrosion resistance}

For corrosion resistance study, steel cathodes were given deposit of varying thicknesses from 5-25 $\mu \mathrm{m}$. The specimens after plating were subjected to bright dip in $1 \%$ nitric acid followed by passivation. The porosity of the deposit was tested with potassium ferricyanide paper. The soaked paper with potassium ferricyanide was placed on the deposit and no blue spots were observed. This test indicated pore free nature of the deposit. Further corrosion resistance test was carried out in a salt spray chamber. The deposited plates, after passivation, were subjected to continuous spray of neutral 5\% sodium chloride solution. The deposit did not show white rust even after $96 \mathrm{~h}$ of testing. This study shows good corrosion resistance of the deposit. 
Table 3. Optimum bath composition and operating conditions.

\begin{tabular}{lcl}
\hline Bath composition & Quantity $\left(\mathrm{gL}^{-1}\right)$ & \multicolumn{1}{c}{ Operating conditions } \\
\hline $\mathrm{ZnSO}_{4} \cdot 7 \mathrm{H}_{2} \mathrm{O}$ & 80 & Anode: zinc metal (99.99\%) \\
$\mathrm{NH}_{4} \mathrm{Cl}$ & 150 & Cathode: mild steel \\
Sodium lauryl sulphate (SLS) & 02 & Temperature: $293-303 \mathrm{~K}$ \\
Condensation product (mLL & Bright current density range: $0 \cdot 5-8 \mathrm{Adm}^{-2}$ \\
& 40 & Plating time (min): 10 \\
& & Agitation: air \\
\hline
\end{tabular}
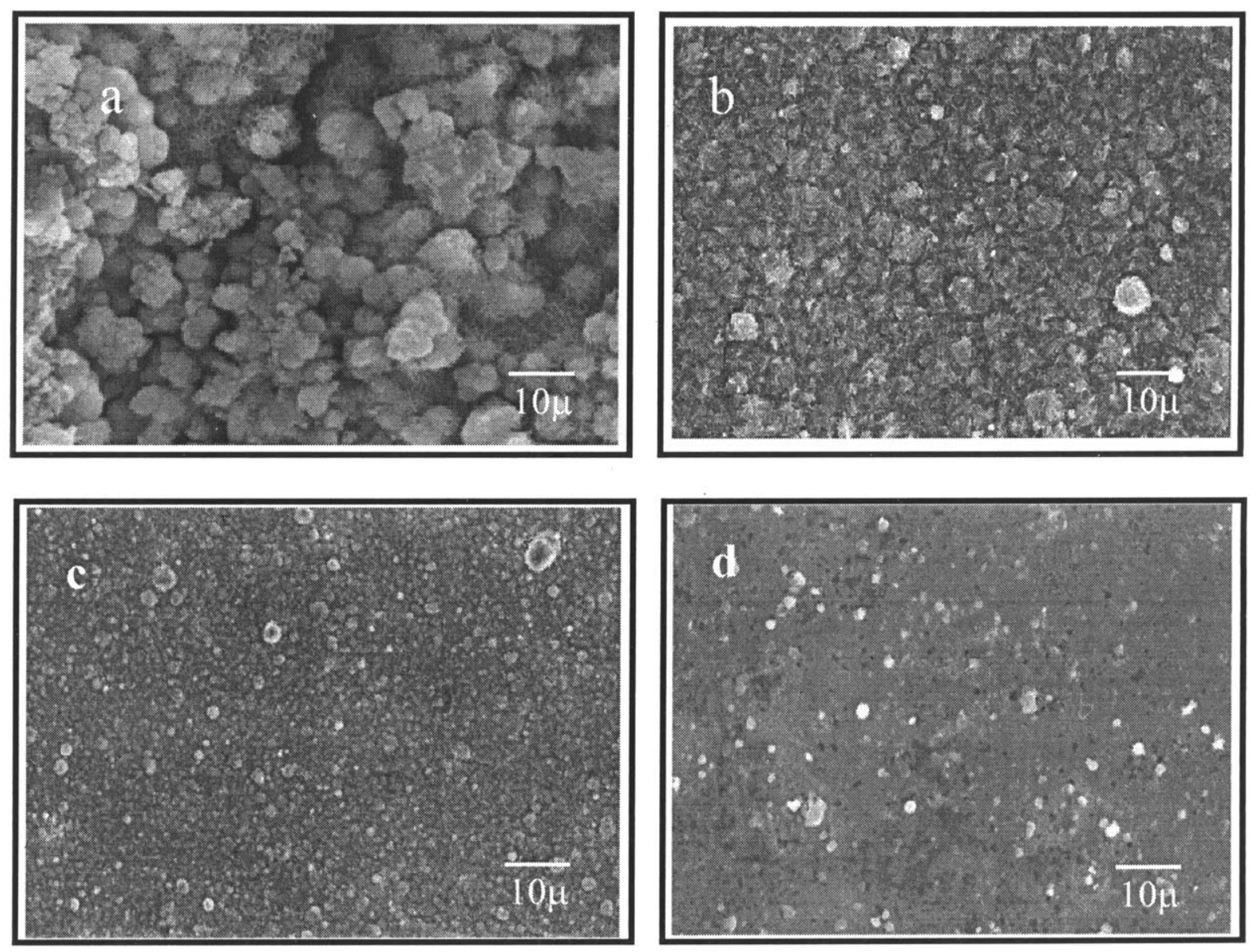

Figure 3. SEM photomicrographs of the deposits obtained at $2 \mathrm{Adm}^{-2}$ in the presence and absence of addition agents at $298 \mathrm{~K}$ : a. basic bath, b. basic bath + veratraldehyde, c. basic bath + condensation product and d. passivated deposit.

\subsection{Metallurgical properties}

Standard bend test was used to measure both adherence and ductility of zinc deposits. Mild steel panels of $1 \mathrm{~mm}$ thick $\left(1 \times 10 \mathrm{~cm}^{2}\right.$ area) were electroplated with zinc to different thicknesses $(5-20 \mu \mathrm{m})$. The samples were subjected to bending through $180^{\circ}$. No crack or peel off in the deposit was noticed even after $180^{\circ}$ bending of the specimen. This indicates the good adherence and ductility of zinc deposit on steel. Zinc thickness of $20 \mu \mathrm{m}$ and load of $50 \mathrm{~g}$ was employed. The microhardness of zinc was found to be 130 .

\subsection{Consumption of brightener}

The amount of condensation product consumed for $1000 \mathrm{amp}-\mathrm{h}$ was $5 \mathrm{mLL}^{-1}$.

\section{Conclusions}

The optimum bath is capable of producing bright deposit over a wide current density range. The throwing power was reasonably good. The brightener can be easily synthesized by the condensation of veratraldehyde and chitosan. The addition agents are non-toxic, easily soluble in water and 


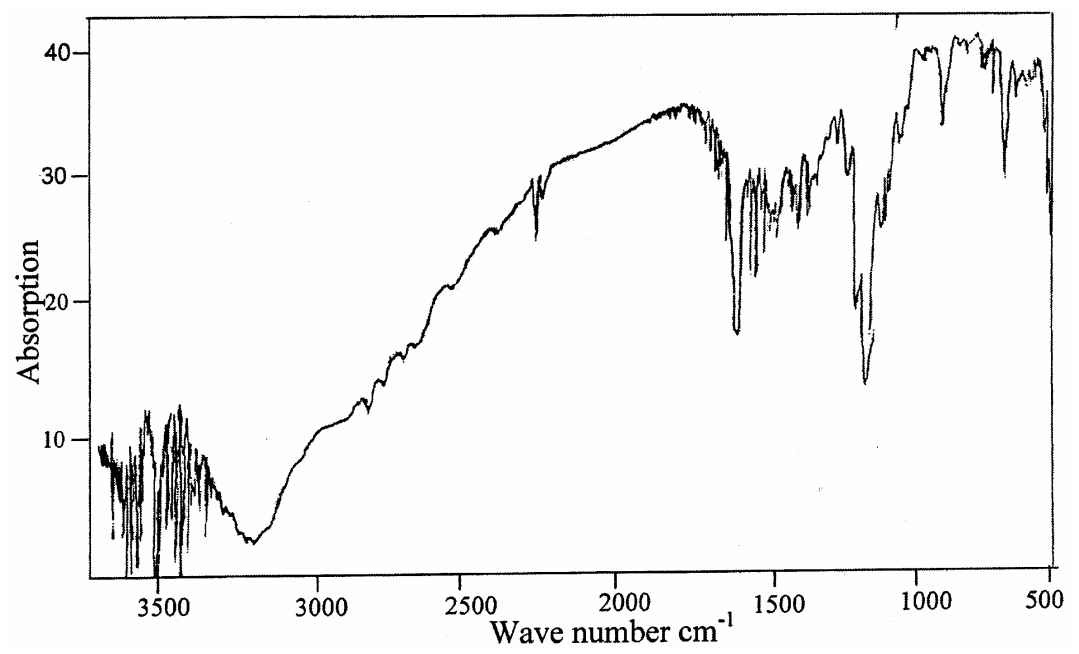

Figure 4. IR spectrum of the scrapped zinc deposit.

hence require no treatment of the effluent. The deposit is pore free and corrosion resistant. The bath appears to be viable for commercialization.

\section{References}

Arthoba Naik Y and Venkatesha T V 2005 Bull. Mater. Sci. 28 495

Arthoba Naik Y, Venkatesha T V and Vasudeva Nayak P 2002 Trans. SAEST 3739

Ashassi-Sorkhabi H, Shaabani B and Seifzadeh D 2005 Electrochim. Acta $\mathbf{5 0} 3446$

Ashur A, Sharon J and Klein I E 1996 Plat. Surf. Finish. 83 58

Baldwin K R and Smith C J E 1996 Trans. Inst. Met. Finish. 74 202
Basker Veeraraghavan, Bata Haran, Samantha P Kumaraguru and Boranko Popov 2003 J. Electrochem. Soc. 150 B131

Brian S Furniss, Antony J Hannford, Peter W G Smith and Austin R Tatchel 1997 Vogel's text book of qualitative chemical analysis (Singapore: ELBS) 5th ed., p. 782

Chen D and Martell A E 1987 Inorg. Chem. 261026

Hoss H and Elias H 1993 Inorg. Chem. 23317

Kariyanna K G and Venkatesha T V 2005 B. Electrochem. 21 547

Kariyanna K G, Arthoba Naik Y and Venkatesha T V 2003 J. Indian Council of Chemists $\mathbf{2 0} 43$

Parthasaradhy N V 1989 Practical electroplating handbook (New Jersey: Prentice Hall Inc) 1st ed., p. 283

Safranck W H 1997 Plat. Surf. Finish. 8545

Senthil Kumar A, Senthil Raja Pandian C, Ayyapparaju J and Ramesh Bapu G N K 2001 B. Electrochem. 17379

Swathirajan S 1986 J. Electrochem. Soc. 133671 